$$
\begin{aligned}
& \text { In support of amnesty international tf } \\
& \text { The Oxford Amnesty Lectures }
\end{aligned}
$$

\section{Religion and rights}

Edited by Wes

Williams 


\section{Religion and rights}

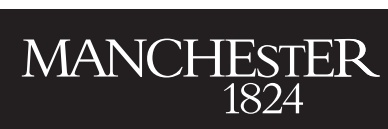

Manchester University Press 
The Oxford Amnesty Lectures

Also available

War on terror: The Oxford Amnesty Lectures 2006, ed. Chris Miller

Incarceration and human rights: The Oxford Amnesty Lectures 2007, ed. Melissa McCarthy 


\section{Religion and rights}

\section{The Oxford Amnesty Lectures 2008}

edited by

Wes Williams

Manchester University Press

Manchester and New York

distributed in the United States exclusively by Palgrave Macmillan 
Copyright (C) Manchester University Press 2011

While copyright in the volume as a whole is vested in Manchester University Press, copyright in individual chapters belongs to their respective authors, and no chapter may be reproduced wholly or in part without the express permission in writing of both author and publisher.

Published by Manchester University Press

Oxford Road, Manchester M13 9NR, UK

and Room 400, 175 Fifth Avenue, New York, NY 10010, USA

www.manchesteruniversitypress.co.uk

Distributed in the United States exclusively by

Palgrave Macmillan, 175 Fifth Avenue, New York,

NY 10010, USA

Distributed in Canada exclusively by

UBC Press, University of British Columbia, 2029 West Mall,

Vancouver, BC, Canada V6T 1 Z2

British Library Cataloguing-in-Publication Data

A catalogue record for this book is available from the British Library

Library of Congress Cataloging-in-Publication Data applied for

ISBN 9780719082542 hardback

ISBN 9780719082559 paperback

First published 2011

The publisher has no responsibility for the persistence or accuracy of URLs for any external or third-party internet websites referred to in this book, and does not guarantee that any content on such websites is, or will remain, accurate or appropriate.

Typeset 10.5/12.5pt GraphArnoPro by Graphicraft Limited, Hong Kong 